\title{
IMPLEMENTASI METODE WEIGTHED PRODUCT PADA SISTEM PENDUKUNG KEPUTUSAN UNTUK PENILAIAN KINERJA KARYAWAN PT. JAMKRIDA
}

Nova Noor Kamala Sari

Universitas Palangka Raya, Kampus Tunjung Nyaho Jalan Yos Sudarso, Palangka Raya, Kalimantan Tengah, Indonesia novanoorks@it.upr.ac.id

\section{ARTICLE INFO}

\section{Keywords}

Decision Support System

Weighted Product

Waterfall

\section{AB STR ACT}

The application of information technology in the field of Human Resource Management greatly facilitates the work of administrative issues in relation to Human Resource. The use of information technology in the processes requires well-trained human resources. As a company that has several units, the Human Resources who work at PT. JAMKRIDA are expected to have good performance to support the company's progress. Therefore, a performance evaluation system is needed.

Decision support system used the Weighted product method to complete the calculation. Software development methodology applied waterfall starting from the requitments definition, system and software design to the implementation phase made by PHP and MyAdmin database, and black box testing.

It is concluded that decision support system for evaluating the employee's performances does assessment by using criteria and items of assessments referring to PT. Jamkrida. Assessments are carried out online so it is expected to replace the manual old system.

\section{Pendahuluan}

Sumber Daya Manusia (SDM) memegang peran penting dalam suatu organisasi atau sebuah perusahaan, semakin maju dan berkembangnya suatu perusahaan maka diharuskan memiliki SDM yang banyak dan untuk itu membutuhkan lebih banyak tenaga juga untuk menjalankannya. SDM yang unggul bukan hanya memiliki fisik yang kuat tetapi diharuskan juga mempunyai daya fikir yang mumpuni guna menunjang produktivitas perusahaan.

Sayangnya dalam perkembangan perusahaan di era digital ini terdapat beberapa permasalahan yang muncul, salah satunya adalah sangat susahnya suatu perusahaan untuk mendapatkan Sumber Daya Manusia dengan skill tertentu yang memang benar- benar dibutuhkan oleh perusahaan. Oleh sebab itu perusahaan harus selektif dalam memilih karyawan dan juga setelah mendapatkan Sumber Daya Manusia yang dibutuhkan harus membekalinya dengan berbagai macam pengetahuan sesuai tuntutan zaman dan tentunya sejalan dengan Visi- Misi perusahaan. Yang tidak kalah pentingnya lagi adalah SDM yang dimiliki sifatnya wajib untuk melek dengan perkembangan teknologi yang sangat dinamis serta dapat memanfaatkan teknologi tersebut guna perkembangan perusahaan dalam mencapai tujuan.

Perkembangan teknologi informasi sangat diperlukan guna mempermudah pekerjaan dan juga mempercepat waktu penyelesaian pekerjaan dalam suatu perusahaan. Teknologi Informasi pada 
perusahaan atau organisasi yang menjadi landasan dari berbagai aplikasi yang berkembang saat ini diantaranya adalah network management, basis data, sistem informasi dan lain sebagainya. Penerapan teknologi informasi dalam bidang Manjemen Sumber Daya Manusia sangat mempermudah dalam melaksanakan berbagai macam pekerjaan baik dari sisi administratif yang dalam hal ini mengatur semua urusan yang berkaitan dengan SDM, penilaian kinerja sumber daya manusia yang nantinya membantu untuk dapat meningkatkan kualitas dan kepuasan sumber daya manusia yang terlibat sehingga mereka dapat bekerja lebih baik.

Dari beberapa point pentingnya penggunaan teknologi informasi yang disebutkan diatas terhadap kemajuan perusahaan, maka PT. JAMKRIDA yang memiliki beberapa unit kerja dirasakan sangat membutuhkan suatu sistem informasi yang cepat, tepat, akurat serta meningkatkan ketelitian dalam proses kerja. Oleh sebab itu maka penulis merasakan sangat perlu membuat sistem pendukung keputusan [1] yang dapat menganalisis kinerja SDM (karyawan) yang dimiliki. Dengan adanya Sistem Pendukung ini nantinya penilaian kinerja karyawan diharapkan dapat menjadi bersifat kuantitatif berdasarkan capaian target, transparan, cepat dan paling penting sebagai hasil akhir adalah sebagai acuan dalam pemberian reward kepada karyawan yang berprestasi.

\section{Metodologi Penelitian}

Metode penelitian yang dilakukan meliputi :

1. Pengumpulan Data [2]

a. Metode Observasi

Observasi dilakukan untuk mengetahui bagaimana PT.Jamkrida dalam menilai kinerja karyawannya.

b. Wawancara (Interview)

Metode Wawancara (Interview) adalah metode yang digunakan penulis untuk mengumpulkan data dengan cara bertanya langsung kepada pihak yang bersangkutan yaitu PT.Jamkrida

c. Studi kepustakaan

Metode Kepustakaan adalah metode yang digunakan penulis untuk mengumpulkan data dengan cara membaca dan mempelajari buku-buku dan literatur yang ada hubungannya dengan Implementasi metode Weight Product dalam sistem pendukung keputusan.[3]

2. Pengembangan Perangkat Lunak

Metodologi pengembangan perangkat lunak yang digunakan dalam pembuatan website ini yaitu menggunakan metodologi waterfall yang dimodifikasi. Tahapan waterfall yang dilakukan yaitu analisis, desain, implementasi dan pengujian [4]

a. Analisis sistem

Proses pencarian kebutuhan difokuskan pada software untuk mengetahui sifat dari aplikasi yang akan dibuat, pemodelan proses bisnis menggunakan Data Flow Diagram (DFD) dan Entity Relationship Diagram (ERD)[5]

b. Desain

Proses ini digunakan untuk membuat "blueprint" software seperti, perancangan basis data dan perancangan antarmuka (interface)

c. Implementasi

Proses ini akan dilakukan pembuatan perangkat lunak sesuai dengan perancangan basis data dan antar muka yang telah dilakukan pada tahap sebelumnya.

d. Pengujian Sistem

Proses pengujian akan dilakukan dengan Blackbox Testing yang disertai dengan melakukan simulasi data. 
[Vol 14 No 1]

[ Januari 2020]

3. Metode Weighted Product (WP), langkah- langkahnya sebagai berikut :

a. Menentukan kriteria dan melakukan pembobotan kriteria.

b. Memberikan nilai setiap alternatif (Ai) pada setiap kriteria $(\mathrm{Cj})$ yang sudah ditentukan, dimana nilai $\mathrm{i}=1,2, \ldots \mathrm{m}$.

c. Melakukan perbaikan bobot untuk menghasilkan nilai $\Sigma$ wj. Rumus yang digunakan untuk perbaikan bobot :

$$
\mathrm{Wj}=\frac{w j}{\sum w j}
$$

d. Menentukan nilai vektor $\mathrm{S}$ dengan mengalikan semua kriteria dengan bobot yang sudah diperbaiki sebelumnya. Rumus yang digunakan untuk menentukan nilai vektor $\mathrm{S}: \mathrm{Si}=\prod$

$$
\mathrm{Si}=\prod_{j}^{n}=1 x_{i j^{w j}}
$$

e. Menentukan nilai vektor $\mathrm{V}$ yang akan digunakan untuk perangkingan. Berikut rumus yang digunakan untuk menentukan nilai vektor $\mathrm{V}: \mathrm{Vi}=\prod \prod$

$$
\mathrm{Vi}=\frac{\Pi_{j}^{n}=1 x_{i j w i}}{\Pi_{j}^{n}=1\left(x_{j}^{*}\right)^{w j}} \quad \text { sederhananya : } \mathrm{Vi}=\frac{s i}{s 1+s 2+\cdots \cdot s n}
$$

f. Membandingkan nilai akhir dari vektor V7. Menemukan nilai urutan alternatif terbaik yang akan menjadi sebuah keputusan.

\section{Hasil dan Pembahasan}

1) Analisis sistem lama

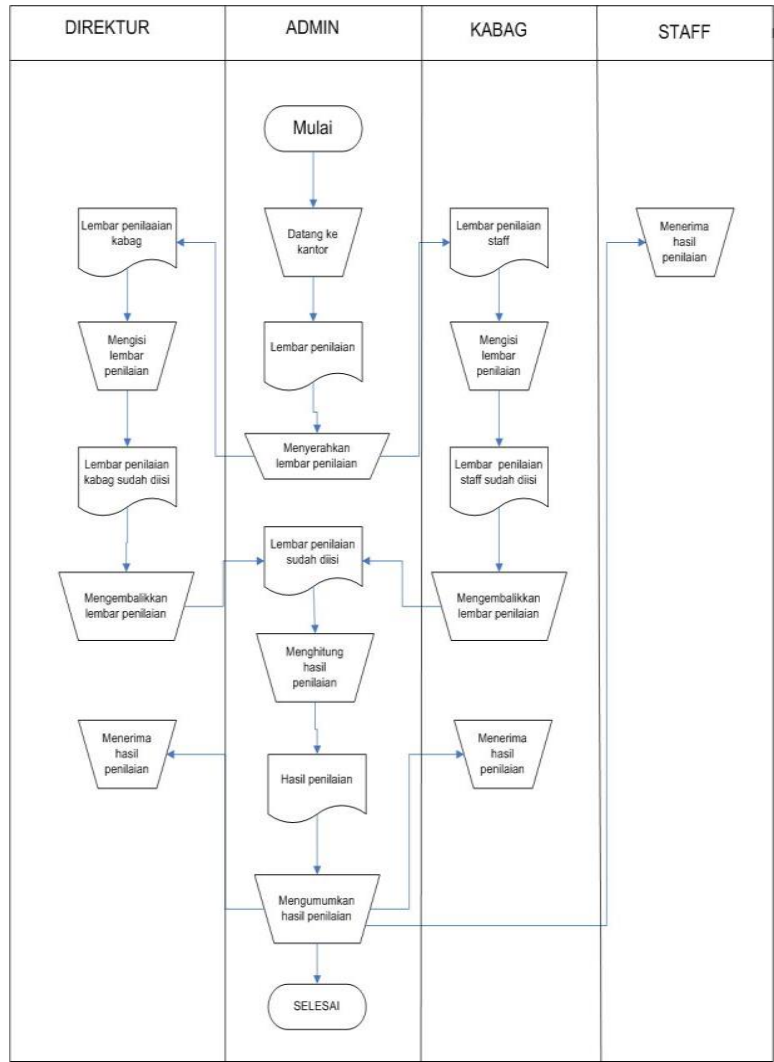

Gambar 1 Flowchart Sistem Lama

2) Analisis Kebutuhan Sistem Baru 


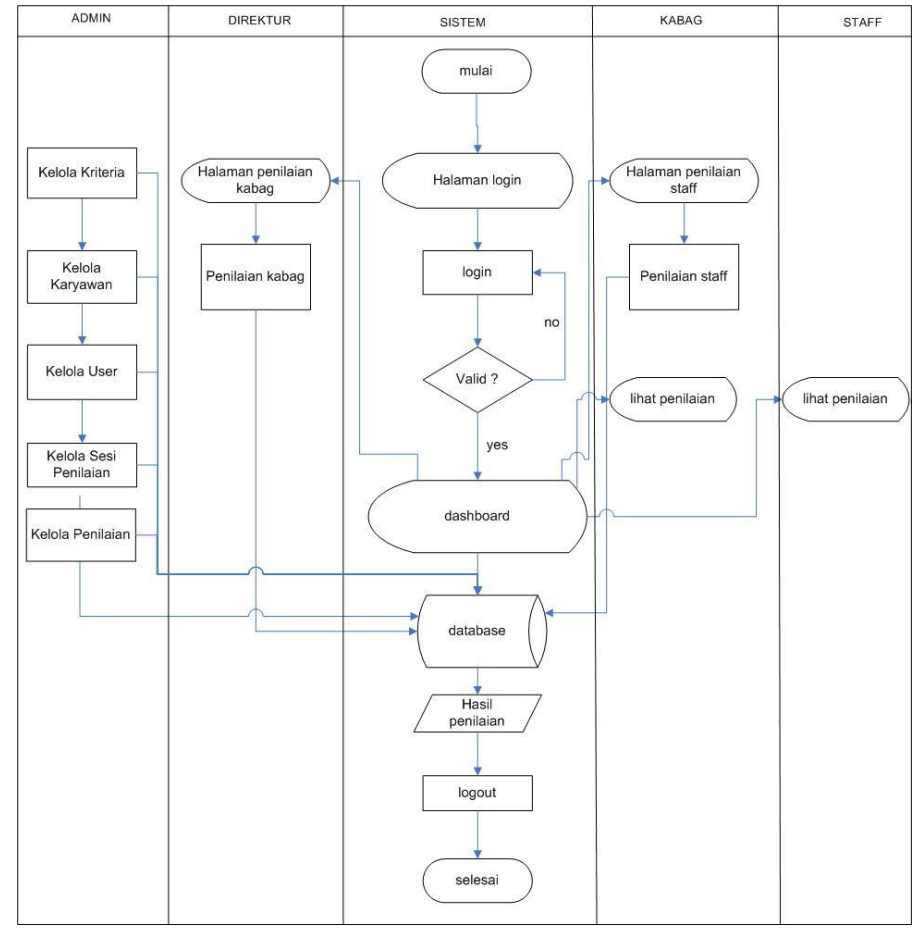

Gambar 2 Flowchart Sistem Baru

3) Perhitungan Metode Weighted Product

Tabel 1 Bobot Kriteria

\begin{tabular}{|c|c|c|}
\hline Kode & Nama Kriteria & Bobot \\
\hline C1 & Penguasaan Pekerjaan & $10 \%$ \\
\hline C2 & Produktivitas dan Kualitas Kerja & $10 \%$ \\
\hline C3 & $\begin{array}{c}\text { Penyesuaian Diri Terhadap } \\
\text { Lingkungan Kerja }\end{array}$ & $10 \%$ \\
\hline C4 & Disisplin dan Tanggung Jawab & $10 \%$ \\
\hline C5 & Komitmen & $10 \%$ \\
\hline C6 & Inisiatif & $10 \%$ \\
\hline C7 & Kerjasama & $10 \%$ \\
\hline C8 & Loyalitas & $10 \%$ \\
\hline C9 & Kemauan Belajar & $10 \%$ \\
\hline C10 & Kreativitas & $10 \%$ \\
\hline
\end{tabular}

Tabel 2 Angka Penilaian

\begin{tabular}{|c|c|}
\hline Angka & Keterangan \\
\hline 100 & Istimewa \\
\hline 90 & Baik Sekali \\
\hline 80 & Baik \\
\hline 70 & Cukup \\
\hline 60 & Kurang \\
\hline 50 & Sangat Kurang \\
\hline
\end{tabular}


4) Perbaikan Bobot

Tahapan weighted product [6] selanjutnya melakukan perbaikan bobot, perbaikan bobot ini yaitu menghitung bobot awal yang sudah ditentukan. Didasarkan pada tabel 1 dimana bobot awal $\mathrm{W}=(10 \%, 10 \%, 10 \%, 10 \%, 10 \%, 10 \%, 10 \%, 10 \%, 10 \%, 10 \%)$ dan akan dilakukan perhitungan seperti pada persamaan 1 . Karena nilai $\mathrm{W}$ menggunakan persen (\%) maka diubah dulu sehingga nilai $\mathrm{W}=0.1,0.1,0.1,0.1,0.1,0.1,0.1,0.1,0.1,0.1$ ).

$$
\begin{aligned}
& W 1=\frac{0.1}{0.1+0.1+0.1+0.1+0.1+0.1+0.1+0.1+0.1+0.1}=0.1 \\
& W 2=\frac{0.1}{0.1+0.1+0.1+0.1+0.1+0.1+0.1+0.1+0.1+0.1}=0.1 \\
& W 3=\frac{0.1}{0.1+0.1+0.1+0.1+0.1+0.1+0.1+0.1+0.1+0.1}=0.1 \\
& W 4=\frac{0.1}{0.1+0.1+0.1+0.1+0.1+0.1+0.1+0.1+0.1+0.1}=0.1 \\
& W 5=\frac{0.1}{0.1+0.1+0.1+0.1+0.1+0.1+0.1+0.1+0.1+0.1}=0.1 \\
& W 6=\frac{0.1}{0.1+0.1+0.1+0.1+0.1+0.1+0.1+0.1+0.1+0.1}=0.1 \\
& W 7=\frac{0.1}{0.1+0.1+0.1+0.1+0.1+0.1+0.1+0.1+0.1+0.1}=0.1 \\
& W 8=\frac{0.1}{0.1+0.1+0.1+0.1+0.1+0.1+0.1+0.1+0.1+0.1}=0.1 \\
& W 9=\frac{0.1}{0.1+0.1+0.1+0.1+0.1+0.1+0.1+0.1+0.1+0.1}=0.1 \\
& W 10=\frac{0.1}{0.1+0.1+0.1+0.1+0.1+0.1+0.1+0.1+0.1+0.1}=0.1
\end{aligned}
$$

\begin{tabular}{|c|c|}
\hline 1. Leo Adano & 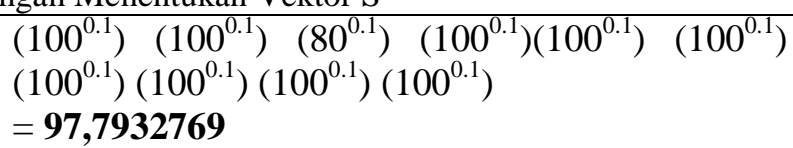 \\
\hline 2. Haqqi Wira Satria & $\begin{array}{l}\left(100^{0.1}\right)\left(100^{0.1}\right)\left(100^{0.1}\right)\left(100^{0.1}\right)\left(100^{0.1}\right)\left(100^{0.1}\right) \\
\left(100^{0.1}\right)\left(100^{0.1}\right)\left(100^{0.1}\right)\left(100^{0.1}\right)=\mathbf{1 0 0}\end{array}$ \\
\hline 3. Diana P. & $\begin{array}{l}\left(100^{0.1}\right)\left(100^{0.1}\right)\left(100^{0.1}\right)\left(100^{0.1}\right)\left(100^{0.1}\right)\left(100^{0.1}\right) \\
\left(100^{0.1}\right)\left(100^{0.1}\right)\left(100^{0.1}\right)\left(100^{0.1}\right)=\mathbf{1 0 0}\end{array}$ \\
\hline 4. Risa Rosari & $\begin{array}{l}\left(100^{0.1}\right)\left(100^{0.1}\right)\left(100^{0.1}\right)\left(100^{0.1}\right)\left(100^{0.1}\right)\left(100^{0.1}\right) \\
\left(100^{0.1}\right)\left(100^{0.1}\right)\left(100^{0.1}\right)\left(100^{0.1}\right)=\mathbf{1 0 0}\end{array}$ \\
\hline 5. Agususanto & $\begin{array}{l}\left(100^{0.1}\right)\left(100^{0.1}\right)\left(100^{0.1}\right)\left(100^{0.1}\right)\left(100^{0.1}\right)\left(100^{0.1}\right) \\
\left(100^{0.1}\right)\left(100^{0.1}\right)\left(100^{0.1}\right)\left(100^{0.1}\right)=\mathbf{1 0 0}\end{array}$ \\
\hline 6. Elvira M. & $\begin{array}{l}\left(80^{0.1}\right)\left(80^{0.1}\right)\left(100^{0.1}\right)\left(100^{0.1}\right)\left(100^{0.1}\right)\left(100^{0.1}\right) \\
\left(100^{0.1}\right)\left(100^{0.1}\right)\left(100^{0.1}\right)\left(100^{0.1}\right)=\mathbf{9 5 , 6 3 5 2 5 0 2}\end{array}$ \\
\hline 7. Dicky Hermawan & $\begin{array}{l}\left(80^{0.1}\right)\left(80^{0.1}\right)\left(80^{0.1}\right)\left(80^{0.1}\right)\left(100^{0.1}\right)\left(100^{0.1}\right)\left(100^{0.1}\right) \\
\left(100^{0.1}\right)\left(100^{0.1}\right)\left(100^{0.1}\right) \\
=\mathbf{9 1 , 4 6 1 0 1 0 3}\end{array}$ \\
\hline 8. Febricius T. & $\begin{array}{l}\left(100^{0.1}\right)\left(100^{0.1}\right)\left(100^{0.1}\right)\left(100^{0.1}\right)\left(100^{0.1}\right)\left(100^{0.1}\right) \\
\left(80^{0.1}\right)\left(80^{0.1}\right)\left(80^{0.1}\right)\left(80^{0.1}\right) \\
=\mathbf{9 1 , 4 6 1 0 1 0 3}\end{array}$ \\
\hline Sangga Daya A. & $\left(80^{0.1}\right)\left(80^{0.1}\right)\left(80^{0.1}\right)\left(80^{0.1}\right)\left(80^{0.1}\right)\left(100^{0.1}\right)\left(100^{0.1}\right)$ \\
\hline
\end{tabular}

5) Menentukan Vektor $S$

Setelah mendapatkan nilai perbaikan bobot dari masing - masing kriteria diatas, kemudian dilakukan perhitungan vektor S seperti pada persamaan 2. Pangkatkan dan kalikan nilai masing - masing kriteria dengan bobot yang sudah diperbaiki sebelumnya.

Tabel 3 Perhitungan Menentukan Vektor S 


\begin{tabular}{|c|c|}
\hline & $\begin{array}{l}\left(100^{0.1}\right)\left(100^{0.1}\right)\left(100^{0.1}\right) \\
=\mathbf{8 9 , 4 4 2 7 1 9 3}\end{array}$ \\
\hline 10. Heru & $\begin{array}{l}\left(80^{0.1}\right)\left(80^{0.1}\right)\left(80^{0.1}\right)\left(80^{0.1}\right)\left(80^{0.1}\right)\left(80^{0.1}\right)\left(80^{0.1}\right) \\
\left(80^{0.1}\right)\left(80^{0.1}\right)\left(80^{0.1}\right) \\
=\mathbf{8 0}\end{array}$ \\
\hline 11. Nurhadi & $\begin{array}{l}\left(80^{0.1}\right)\left(80^{0.1}\right)\left(80^{0.1}\right)\left(80^{0.1}\right)\left(80^{0.1}\right)\left(80^{0.1}\right)\left(80^{0.1}\right) \\
\left(80^{0.1}\right)\left(80^{0.1}\right)\left(80^{0.1}\right) \\
=\mathbf{8 0}\end{array}$ \\
\hline 12. Rio & $\begin{array}{l}\left(80^{0.1}\right)\left(80^{0.1}\right)\left(80^{0.1}\right)\left(80^{0.1}\right)\left(80^{0.1}\right)\left(80^{0.1}\right)\left(80^{0.1}\right) \\
\left(80^{0.1}\right)\left(80^{0.1}\right)\left(80^{0.1}\right) \\
=\mathbf{8 0}\end{array}$ \\
\hline 13. Monalianari $\mathrm{p}$. & $\begin{array}{l}\left(80^{0.1}\right)\left(80^{0.1}\right)\left(80^{0.1}\right)\left(80^{0.1}\right)\left(80^{0.1}\right)\left(80^{0.1}\right)\left(80^{0.1}\right) \\
\left(80^{0.1}\right)\left(80^{0.1}\right)\left(80^{0.1}\right) \\
=\mathbf{8 0}\end{array}$ \\
\hline 14. Ricky & $\begin{array}{l}\left(80^{0.1}\right)\left(80^{0.1}\right)\left(80^{0.1}\right)\left(80^{0.1}\right)\left(80^{0.1}\right)\left(80^{0.1}\right)\left(80^{0.1}\right) \\
\left(80^{0.1}\right)\left(80^{0.1}\right)\left(80^{0.1}\right) \\
=\mathbf{8 0}\end{array}$ \\
\hline
\end{tabular}

6) Menentukan vektor perangkingan atau hasil nilai V dari setiap alternatif Setelah mendapatkan nilai dari masing masing preferensi pada perhitungan diatas, kemudian menghitung untuk mencari nilai vektor $\mathrm{v}$, perhitungannya menggunakan persamaan 3 .

Diana P. (V1)

Risa Rosari (V2)

Agususanto (V3)

Elvira M. (V4)

Dicky Hermawan (V5)

Febricius T. (V6)

Sangga Daya A.(V7)

Heru (V8)

Nurhadi (V9)

Rio (V10)

Monalianari P. (V11)

Ricky (V12)

$$
\begin{array}{r}
=\frac{\mathbf{1 0 0}}{1174,33226}=0.0851547755 \\
=\frac{\mathbf{1 0 0}}{1174,33226}=0.0851547755 \\
=\frac{\mathbf{1 0 0}}{1174,33226}=0.0851547755 \\
=\frac{\mathbf{9 5 , 6 3 5 2 5 0 2}}{1174,33226}=0.0814379826 \\
=\frac{\mathbf{9 1 . 4 6 1 0 1 0 3}}{1174,33226}=0.077883418 \\
=\frac{\mathbf{9 1 . 4 6 1 0 1 0 3}}{1174,33226}=0.077883418 \\
=\frac{\mathbf{8 9 . 4 4 2 7 1 9 3}}{1174,33226}=0.0761647468 \\
=\frac{\mathbf{8 0}}{1174,33226}=0.0457733096 \\
=\frac{\mathbf{8 0}}{1174,33226}=0.0681238204 \\
=\frac{\mathbf{8 0}}{1174,33226}=0.0681238204 \\
=\frac{\mathbf{8 0}}{1174,33226}=0.0681238204 \\
=\frac{\mathbf{8 0}}{1174,33226}=0.0681238204
\end{array}
$$

Perankingan nilai berdasarkan perhitungan weigthted product: 
Tabel 3.8 Perangkingan nilai

\begin{tabular}{|c|c|}
\hline Nama & Nilai Vektor V \\
\hline Diana P. & 0.0851547755 \\
\hline Risa Rosari & 0.0851547755 \\
\hline Agususanto & 0.0851547755 \\
\hline Elvira M. & 0.0814379826 \\
\hline Dicky Hermawan & 0.077883418 \\
\hline Febricius T. & 0.077883418 \\
\hline Sangga Daya A. & 0.0761647468 \\
\hline Heru & 0.0681238204 \\
\hline Nurhadi & 0.0681238204 \\
\hline Rio & 0.0681238204 \\
\hline Monalianari P. & 0.0681238204 \\
\hline Ricky & 0.0681238204 \\
\hline
\end{tabular}

Perangkingan diatas merupakan hasil akhir dari penilaian kinerja ke-12 karyawan PT. Jamkrida pada tahun 2018, bahwa nilai terbesar dari ke-12 data ada 4 orang karyawan yang mendapatkan nlai tertinggi dan ada 5 orang karyawan yang mendapatkan nilai terendah.

Data Flow Diagram (DFD)

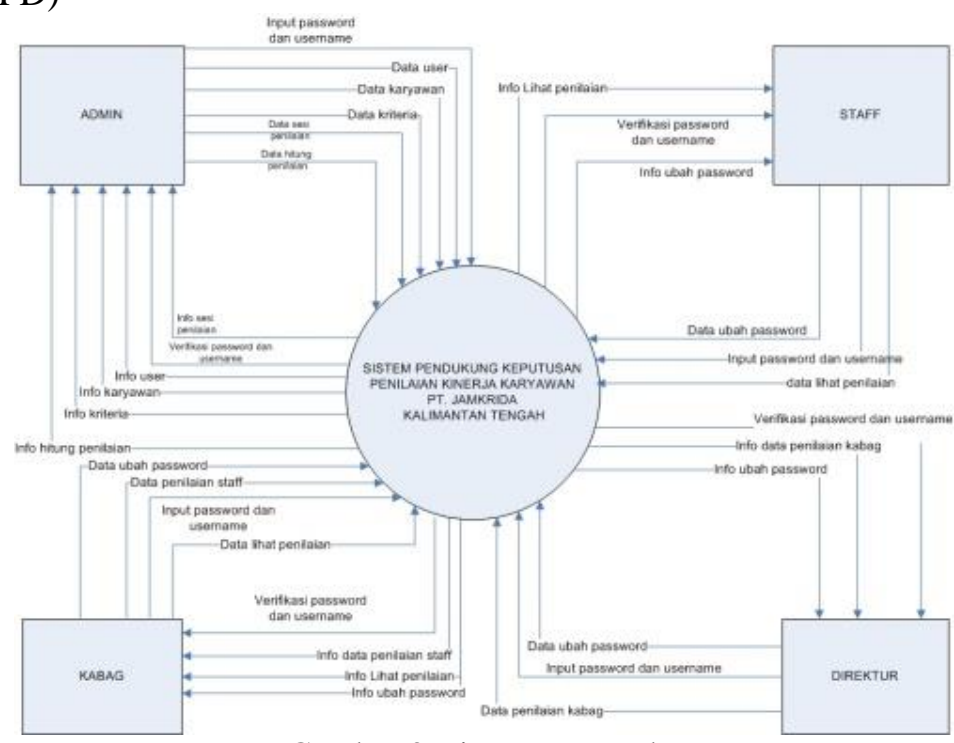

Gambar 3 Diagram Konteks 


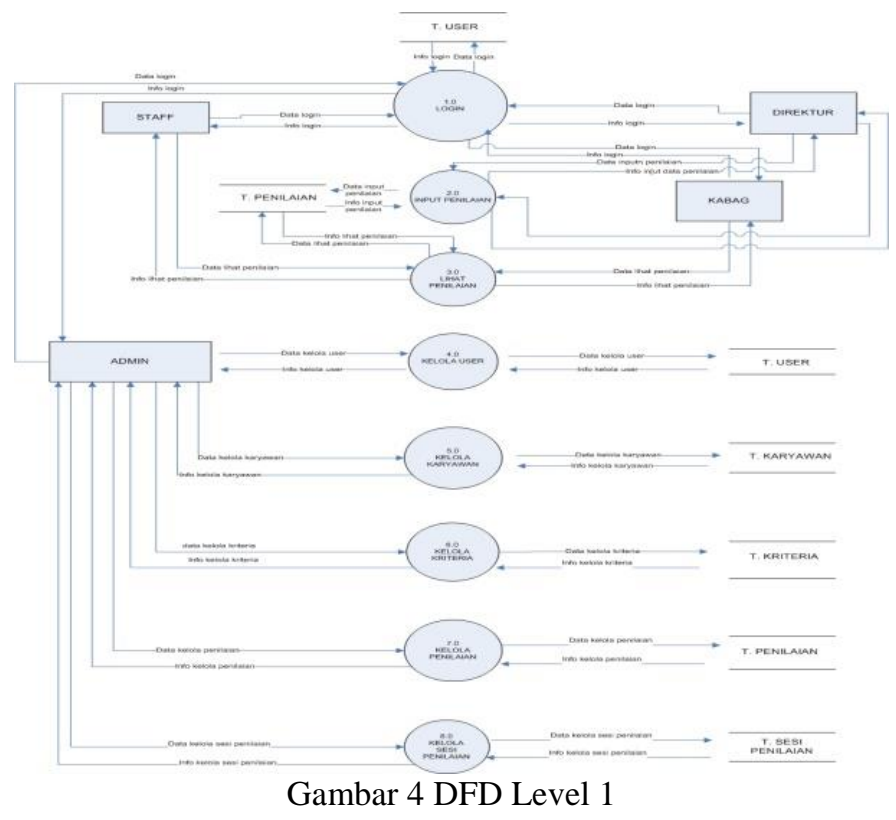

Entity Relational Diagram (ERD)

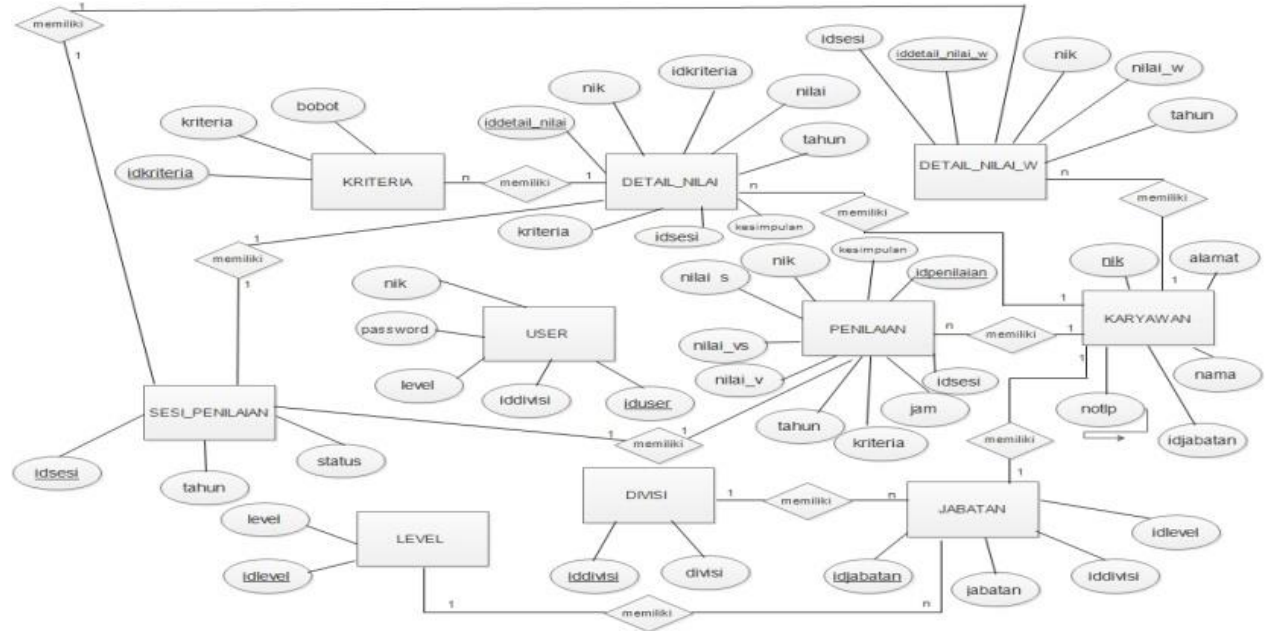

Gambar 5 Entity Relational Diagram

Implementasi Antarmuka

a. Halaman Krieria Penilaian

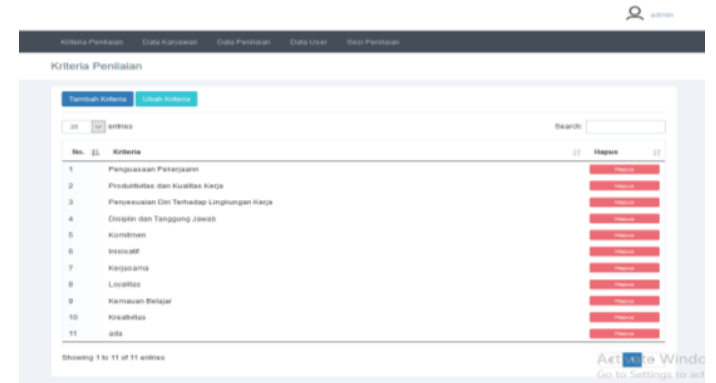

Gambar 6 Halaman Kriteria Penilaian 
b. Halaman Data Karyawan

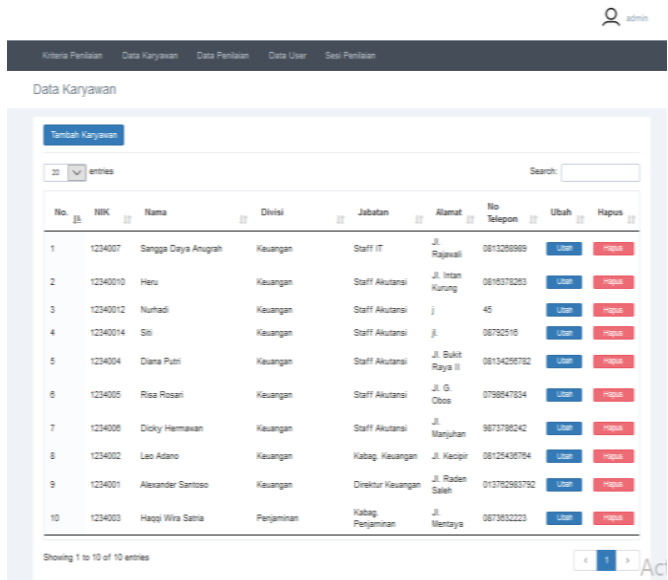

Gambar 7 Halaman Data Karyawan

c. Halaman Hitung Weighted Product 


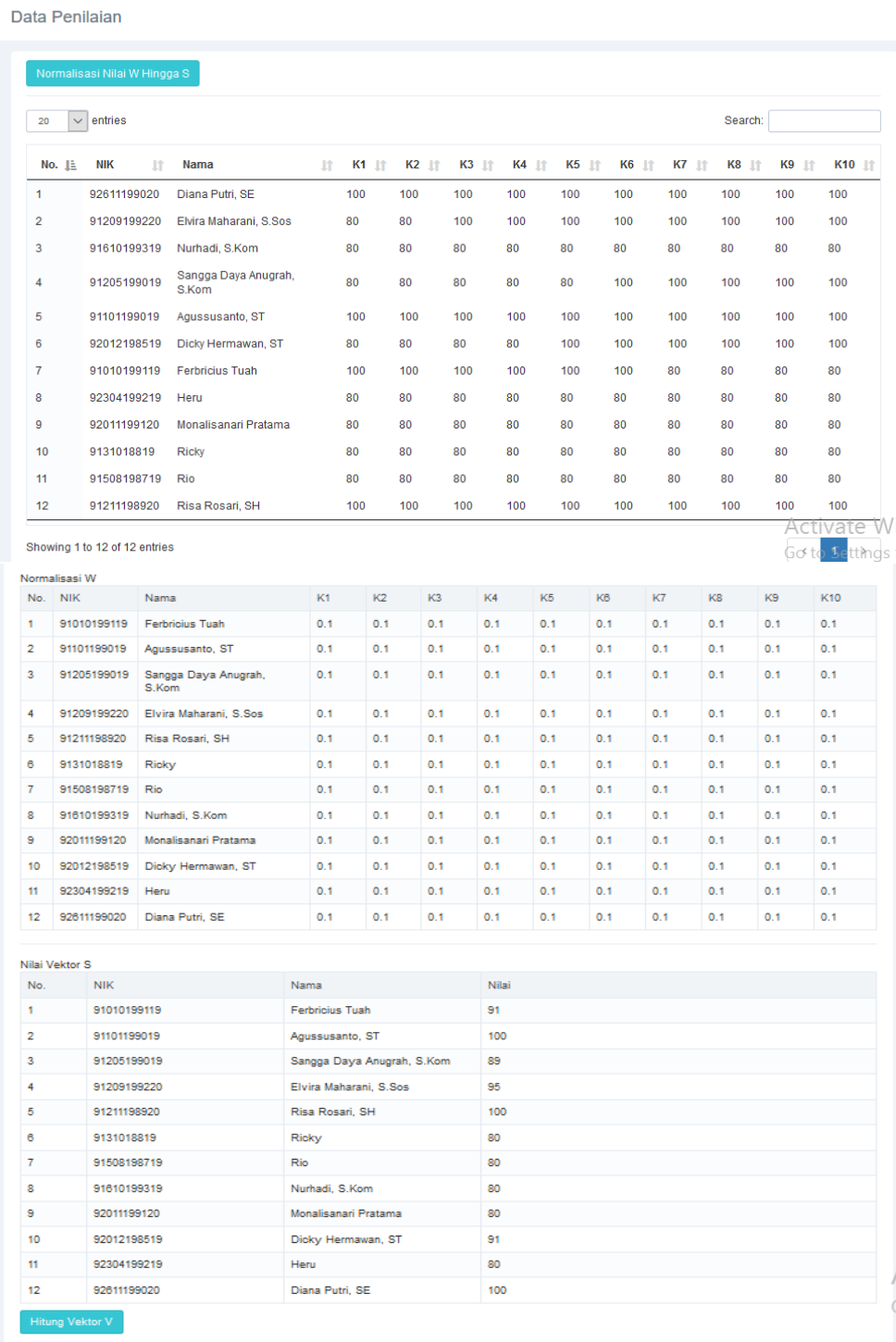

Gambar 8 Halaman Hitung Weighted Product

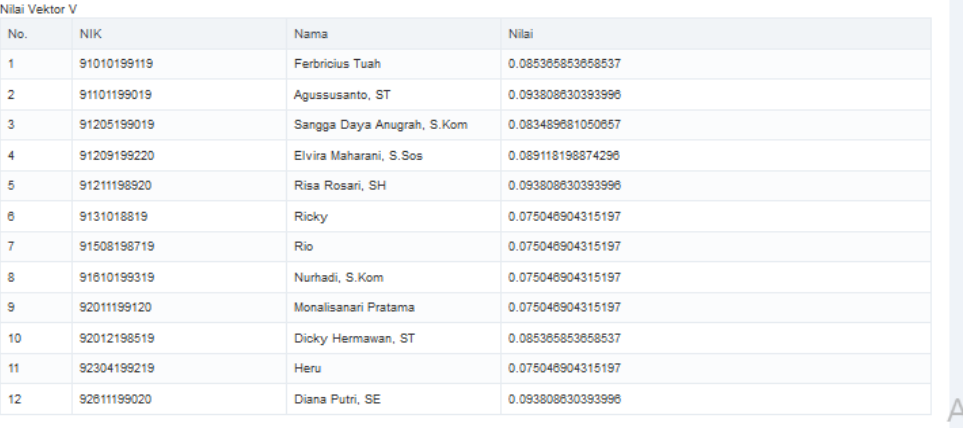

Gambar 9 Halaman Hitung Weighted Product 


\section{Kesimpulan}

Implementasi Metode Weighted Product pada Sistem Pendukung Keputusan ini dibuat dengan menggunakan bahasa pemprograman PHP dan software database menggunakan MYSQL. Metodologi pengembangan perangkat lunak menggunakan waterfall yang dimodifikasi yaitu tahap analisis, desain, implementasi, dan pengujian.

Metode yang digunakan yaitu metode Weighted Product (WP), dengan tahapan yaitu: menentukan kriteria-kriteria,dan menentukan bobot kriteria, memberikan nilai pada setiap alternatif, melakukan normaliasi $\mathrm{W}$, menghitung nilai vektor $\mathrm{S}$ dan menghitung nilai vektor $\mathrm{V}$. Berdasarkan hasil pengujian black box semua fitur dalam sistem telah berjalan dengan baik serta hasil perhitungan dapat digunakan sebagai acuan pemberian reward kepada karyawan.

\section{Daftar Pustaka}

[1] N. N. K. Sari, W. Widiatry, and N. Chitayae, "Sistem Pendukung Keputusan untuk Seleksi Penerima Beasiswa BBP-PPA dengan Metode TOPSIS berbasis Web," anterior J., vol. 18, no. 1, pp. 86-91, 2018.

[2] L. Licantik and N. N. K. Sari, "Pengembangan Media Informasi Ruang Kuliah Pada Fakultas Teknik Universitas Palangka Raya Berbasis Android dan Location Based Service," J. Teknol. Inf., vol. 13, no. 2, pp. 30-36, 2019.

[3] E. Tuban, Decision Support System and Intelligent Systems Edisi Bahasa. Yogyakarta: Andi., 2005.

[4] N. N. K. Sari, P. B. A. A. Putra, and E. Christian, "RANCANG BANGUN APLIKASI MOBILE LEARNING TENSES," J. Teknol. Inf., vol. 13, no. 2, pp. 37-46, 2019.

[5] R. A. S. and M. Shalahuddin, Rekayasa Perangkat Lunak Terstruktur Dan Berorientasi Objek. Bandung: Informatika, 2013.

[6] M. . Khairina, A. M.R., and R. H. Hatta, "Decision Support System For New Employee Recruitment Using Weighted Product Method," ICITACEE, vol. 3, pp. 297-301., 2016. 